\title{
LOCAL GOVERNANCE COLLABORATION MODEL FOR PRESERVING MARINE ECOSYSTEM IN THE COASTAL AREA OF NUSA LEMBONGAN ISLAND, KLUNGKUNG REGENCY, BALI
}

\author{
By \\ Ida Ayu Putu Sri Widnyani ${ }^{1)}$, I Made Kusna Antara ${ }^{2}$, Nyoman Diah Utari Dewi ${ }^{3)}$ \\ Magister Administration Science, Postgraduate, Ngurah Rai University \\ dayusriwid@gmail.com
}

\begin{abstract}
The marine ecosystem on the coast of Nusa Lembongan is one of the tourist attractions such as coral reefs, mangrove forests and others. The high number of tourist visiting the island also impacts tourism facilities. Increased tourism also has the opportunity to damage the marine ecosystem. Therefore needs a collaboration among stakeholders in maintaining the sustainability of the marine ecosystem

The purpose of this research is to find out and analyze also to find a collaborative model of stakeholders such as government, private sector, community and traditional institutions in preserving the marine ecosystem in Nusa Lembongan. The research is using a qualitative descriptive approach with determining informants technic is purposive sampling.

Local government collaboration model in conserving marine ecosystems by strengthening the role of stakeholders at the local level such as: 1) signing memorandum of understanding for creating regional regulations as a policy of the Klungkung Regency; 2) writing in to a local wisdom (awig-awig) as a local policy of the local wisdom institutions (adat); 3) writing into the policy of the tour operator; 4) implement the Tri Hita Karana concept and creating a memorandum of understanding for all parties.
\end{abstract}

Key words: Collaboration Model, Local Governance, Marine Ecosystem and Tri Hita Karana.

\section{Introduction}

Nusa Lembongan is a small island located in the southeast of the island of Bali. This island which is $4.6 \mathrm{~km}$ long and 1-1.5 km wide is approximately $11 \mathrm{~km}$ to the southeast of Bali, or $2 \mathrm{~km}$ to the northwest of Nusa Penida Island. Administratively, this island includes the Nusa Penida District, Klungkung Regency, Bali Province. Pekraman Lembongan village covers two small islands, namely Lembongan Island and Ceningan Island which are mostly surrounded by sloping beaches and several steep cliffs.

The beach on the island of Lembongan, is a beach in general which is a gift or zone between the edges of the sea waters at low tides to the effective limit of the influence of waves towards the land. While the coastline is a line where land and water meet whose position changes according to the condition of the water level due to tides.

The coastal typology is the result of the interaction of dynamic processes from geological aspects (including topography, lithology, hydrology, volcanic activity, tectonic and sedimentation processes); geophysics includes weather (rain, wind, currents, waves and tides); and human activity factors include taking materials both offshore, coast and land, coastal buildings, and onshore development activities. Interaction between several factors mentioned above produces different beach characteristics between one beach and another.

The beauty of the coast of Lembongan island, makes this island a tourism spot that promises the beauty of the sea. On the island of Lembongan, in addition to being famous for its white sandy beaches, it also develops well-known marine biota such as seaweed, coral, seagrass beds, mangroves and several types of marine fish. 
The beauty of the sea is used by tourism actors to develop tourism business on the island of Lembongan. Sudiarta (2015) stated that the preservation of coral reefs around the coast on the island of Lembongan strongly supports the development of marine tourism that developed on the island of Lembongan. Ginantra (2014), increasing population of bird species in the mangrove forests on Lembongan Island has a positive impact on the sustainability of several species of birds and the continuation of foreign guests visiting Lembongan Island. This is in line with the records made by the Department of Tourism and Culture of the Klungkung Regency, which made the increase in tourism visits to Klungkung Regency during 2016 amounted to 9\%, and the largest occurred to Lembongan and surrounding islands. Records of tourism visits in the office of the head of Lembongan village, also showed the same thing that during 2015 and 2016 there was an increase in tourist visits by 14\%, especially tourists from Russia, Australia, China, and several other European countries.

The development of seaweed on the island of Lembongan which began around the 1980s at least caused some problems to the sustainability of the function of marine biota. Many local people dig wild coral reefs to be used as seaweed cultivation areas. Likewise, there are several logging of mangrove forests used by the population for supporting seaweed cultivation. Some seagrass meadows habitats are often crushed by residents for seaweed cultivation areas.

The rapid development of tourism on the island of Lembongan, in addition to having a positive impact on the population of Lembongan, also had a negative impact on some marine biota. The development of tourism industry facilities such as boats, jukung, sea vessels, also affects the sustainability of marine biota. Supporting facilities for the tourism industry requires berths and leaning that will damage marine biota due to anchors, basic scouring of ships, and sea transport activities.

The aim to be achieved in this study is to find out the use of local wisdom in the form of institutional strengthening in Pekraman Lembongan village in saving coastal ecology that exists on the island of Lembongan. In this study, the existence of institutions in Pekraman Lembongan village that have a role in saving coastal ecology. In addition, it is necessary to know how the ecological conditions of the coastal island of Lembongan are by strengthening the traditional institutions in Pekraman Lembongan village.

This research is expected to provide actual information about the existing coastal ecological conditions on Lembongan island in the form of coral reefs, seagrass beds, mangrove forests and coastal conditions. The results achieved are expected to be useful for policy makers to provide alternative solutions to save coastal ecology in the islands. This result can also be used as a form of marine-based curriculum development by utilizing local wisdom that develops and has a positive impact on the sustainability of coastal ecology.

Coastal ecological sustainability on the coast of Lembongan Island needs to be carried out continuously. The preservation of coastal ecology on the island of Lembongan has a double benefit, besides being a tourist attraction that promises the beauty of the sea, as well as supporting local residents who mostly work as seaweed farmers. The preservation of coastal ecology on the island of Lembongan also serves to prevent abrasion that erodes the island of Lembongan. Erosion / abrasion is one of the important beach issues on the island of Lembongan. The length of the beach that experienced abrasion on the island of Lembongan in 2010 was 970 meters and only 326 meters had been handled so that there were still beaches that experienced abrasion that had not been handled along 644 meters (Balai BaliPenida River Region, 2009, in Sudiarta, 2015).

Dredging sand dunes in coastal areas carried out by residents who inhabit the island of Lembongan can result in changes in the natural protection of the beach. This will change the energy dissipation on the beach. If this change increases the wave energy in a part of the coast, energy will occur in that section. Sand mining and other coastal materials directly reduce coastal sediments and reduce coastal elevation. Beach erosion that occurred on the island of Lembongan is also exacerbated by sand mining or beach material activities.

Mangrove forest area on the island of Lembongan is entirely a mangrove forest area of 202.0 ha. Mangrove forests in this forest area include protected forest areas. Utilization of the area of magrove forest around the coast of the island of Lembongan is increasingly pressed due to the development of tourism which requires extensive land for tourism accommodation on the beach. Although according to Sudiarta (2015), the condition of the magrove forest on Lembongan Island is classified as a good 
category, but the researchers observed that there are several places where mangrove forests have undergone a function change. Beaches that surround the island of Lembongan which are very rich in marine ecology such as coral reefs, seagrass beds, seaweed, and ornamental fish need to get attention to the sustainability of its existence and sustainability of its functions.

In the face of some of the above phenomena, Pekraman village in Lembongan strengthens several traditional institutions to preserve the sustainability of several ecologies around the coast of the island of Lembongan. Strengthening these institutions functioned in the function of institutions that directly manage coastal marine ecology preservation around the coast of the island of Lembongan. This effort needs serious attention as a form of Pekraman village involvement in conserving the marine environment. Efforts made by Pekraman Lembongan village can be adopted as a form of utilizing local wisdom in saving the coastal environment and can be used to develop a marine-based curriculum that utilizes local wisdom.

This study will specifically examine the impact of institutional strengthening in Pekraman village in Lembongan to save the sustainability of coastal ecology around the coast of the island of Lembongan. In accordance with the explanation above, the focus of the problem in this study is the extent to which the role of institutions in Lembongan Island is in saving the coastal marine ecosystem of Lembongan Island towards the development of tourism. The existence of coastal seas on Lembongan Island if it is not immediately sought for a solution will cause the sustainability of the sea coast of Lembongan Island to be threatened.

Institutional strengthening is the traditional institutions in Lembongan Island such as Pekraman Village, Banjar-banjar adat, sekaa-sekaa, and traditional institutions that develop on Lembongan Island. While the official agencies are official villages, Nusa Penida KKP, Tourism Office, and Klungkung Regency Marine and Fisheries Service.

Based on the background of the problems described above, the formulation of the problems to be studied further can be formulated as follows: "What are the efforts of 3 pillars of governance in saving the coastal marine ecosystem of Lembongan Island towards the development of tourism on Lembongan Island?

\section{Methodology}

This study uses a qualitative descriptive research method. The qualitative research intended by Strauss and Corbin as a type of "research whose findings are not obtained through statistical procedures or other forms of calculation. Examples can be in the form of research about a person's life, history and behavior, as well as about the role of the organization, social movements or reciprocal relations. (Strauss and Corbin, 2009; 4).

Based on the opinion of Strauss and Corbin above, it means that this research method is appropriate because it analyzes the role and model of the institutions involved in ecosystem conservation in Nusa Lembongan. Determination of informants using purposive sampling, and data collection techniques through observation, documentation, interviews and data search on line. While the data analysis technique uses the interactive Miles Huberman Model namely, data collection, verification reduction and conclusion drawing.

\section{Discussion}

Lembongan can be reached from several places on the island of Bali by using sea transportation facilities such as jukung, boats and ships from the beaches of Sanur, Tanjung Benoa, and several beaches in the Kusamba area, Klungkung. In general the existence of Lembongan island is presented in the following figure. 


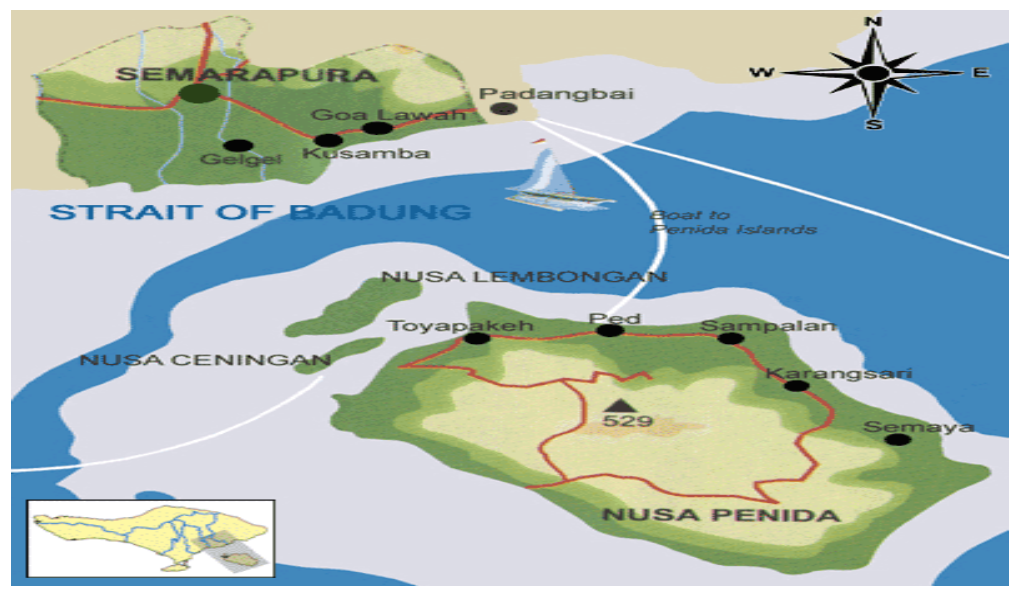

Figure 1. Position of Lembongan Island as a Small Island in Bali

Several places on the coast of Lembongan island are well developed, some marine ecologies such as coral reefs, seagrass beds, mangroves, seaweed, and some ornamental fish. The existence of marine ecology strongly supports the survival of the population of Lembongan island, both as food and as a natural resource that is utilized by the people of Lembongan island. Some marine biota that develop around the coast of Lembongan island are presented in the following figure.

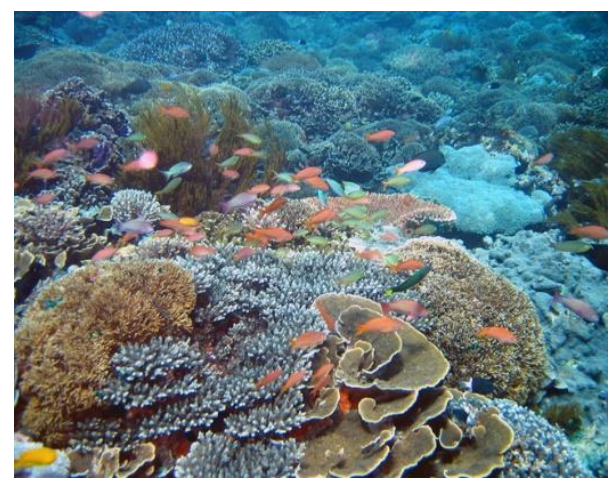

Figure 2. Coral Reefs at Crystal Bay

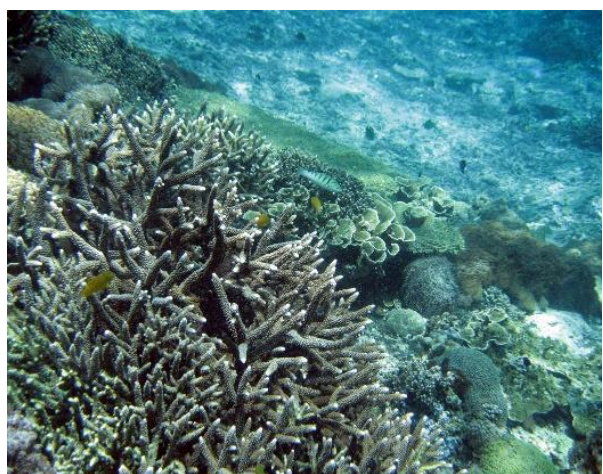

Figure 3. Coral Reefs at Nusa

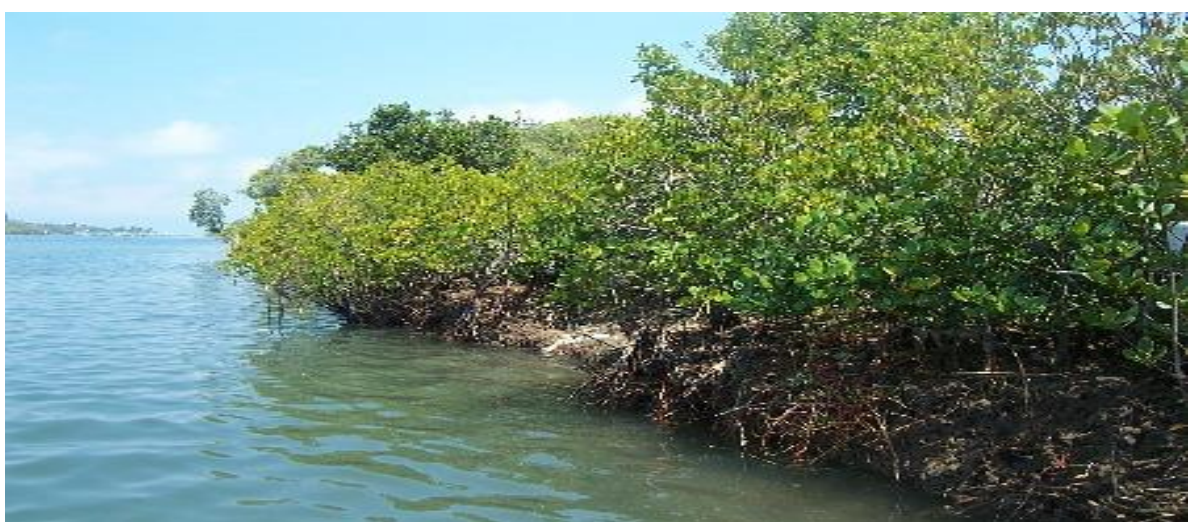

Figure 3. One of the Mangrove Forest Areas on Lembongan Island 


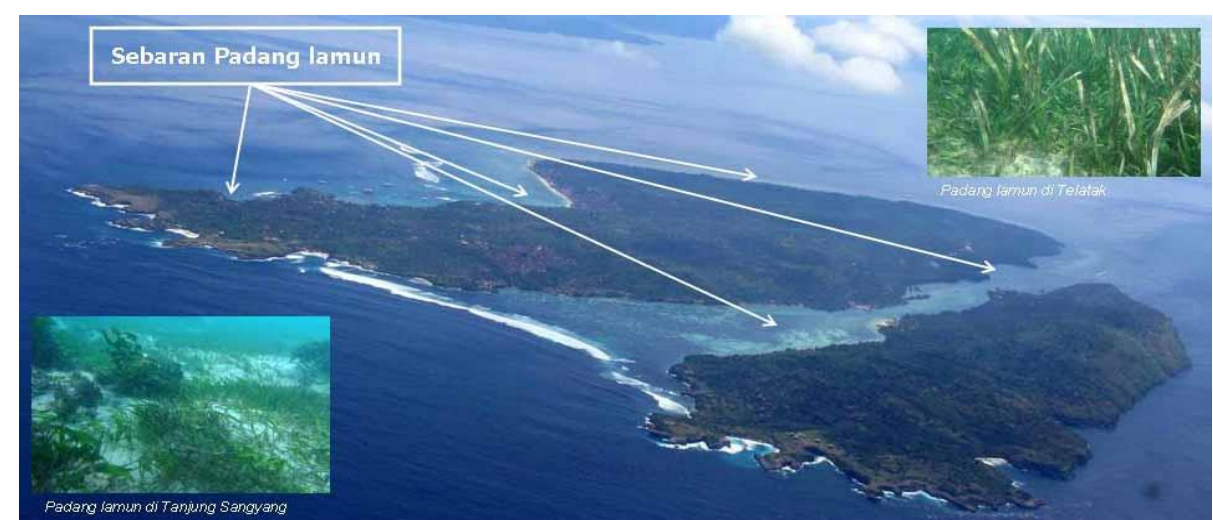

Figure 5. Seagrass habitat in Nusa Lembongan and Nusa Ceningan

In the picture above, it is presented that the marine ecosystems in Lembongan Island develop in certain areas and are very closely related to tourism objects. Mangrove forests in the east and southeast of Lembongan Island are used as magrove tourism objects by involving local residents.

The efforts made by the 3 governance pillars in Lembongan Island can be explained as follows. Based on the results of interviews conducted by researchers on several Klungkung District Offices including:

I Dewa Gede Wisasta (Secretary of the Klungkung Tourism Office), the researcher asked what the Klungkung Regency Government had done to preserve the marine ecosystems in Lembongan Island.

"The Klungkung Regency Government has formed a Marine Conservation Area (KKP) specifically designed to protect and supervise the marine natural resources contained in it from damage such as bombings, poisons, illegal fishing and placed as one of the UPTs in Nusa Penida. This effort is in line with Law No. 27/2007 concerning Management of Coastal Areas and Small Islands and Law No. 45/2009 concerning Fisheries. The Klungkung Regency Government is only based on these two laws in managing the marine ecosystem in Lembongan Island. The formation of a special KKP placed in Nusa Penida is also based on these two laws. (Interview on June 9, 2018).

I Dewa Ketut Yogi Palguna, S.Sos (Nusa Penida KKP Office Staff), the researcher asked what was done by the KKP Office in maintaining or preserving the marine ecosystem in Lembongan Island: Nusa Penida KKP has carried out activities in accordance with the functions and tasks of protecting and supervising the marine natural resources contained within it from damage such as bombing, poisoning, illegal fishing such as conducting patrols, socializing to fishermen, socializing to nautical entrepreneurs and students as well as doing rehabilitation of corals and avoiding marine pollution, such as removing waste and plastic waste into the sea (Interview on June 10, 2018).

I Ketut Astawan (Palm Grove Villas owner), the researcher asked what tourism actors in Lembongan Island had done in participating in preserving the marine ecosystem on Lembongan Island:

The participation of tourism actors in safeguarding marine ecosystems by not disposing of hotel sea waste, gives education to tourists by not damaging coral reefs when carrying out diving (Interview on 11 June 2018).

I Nyoman Suwirta (Owner of Sadeg Villa), researchers asked what tourism actors in Lembongan Island had done in participating in preserving the marine ecosystem on Lembongan Island: The role of the private sector, especially those engaged in tourism, has formulated together to participate in the conservation of marine ecosystems in Lembongan Island. This effort is often 
initiated together with the Klungkung Regency Government in the form of the Nusa Penida Festival which has been conducted 4 times, namely in Sampalan, Lembongan, Banjar Nyuh, and Jungutbatu. In the Nusa Penida Festival activity, the private sector and the Klungkung Regency Government invited the relevant ministries to jointly engage in the conservation of the marine ecosystem on Lembongan Island. One of the activities in question is mangrove planting, coral reef planting, beach cleaning, and general knowledge about the sustainability of marine ecosystem functions on Lembongan Island. (Interview on June 11, 2018)

Based on the results of interviews conducted by researchers on several communities on Lembongan Island including: I Ketut Subagia (Lembongan Island Community), the researchers asked what the people of Lembongan Island were doing to participate in conserving the marine ecosystem of Lembongan Island:

Even though the community does not fully do the marine ecosystem in Lembongan Island wisely. For example, in catching fish the community does not use tools or chemicals anymore but uses simple tools such as nets, hooks or other simple tools that are environmentally friendly. The community also follows the directions in the socialization carried out by the related agencies about the importance of safeguarding the marine ecosystem and trying to follow the awig-awig that applies in the customary organization of Lembongan Island. (Interview on June 11, 2018)

I Made Serman (Lembongan Island Community), the researchers asked what the people of Lembongan Island were doing to participate in conserving the marine ecosystem of Lembongan Island: The role of the community in saving the environment in the Lembongan area is nothing but by actively participating in dealing with active waste, giving an appeal to tourism actors not to dispose of waste carelessly, giving direction to the younger generation to always behave in a clean life, especially to the environment so that whatever is about environmental damage can be overcome. (Interview on June 11, 2018).

The Klungkung Regency Government has not yet formed a Regional Regulation (Perda) which specifically discusses the preservation of the function of the marine ecosystem on Lembongan Island, whereas the Regional Regulation is important as a control material in the conservation of marine ecosystems on the coast. The Klungkung Regency Government has streamlined the function of the Tourism Office, KKP Office and the Environmental Agency of Klungkung Regency in managing the marine ecosystem in Lembongan Island.

Based on the results of interviews and document recording conducted by researchers, the role of 3 pillars of governance in the preservation of marine ecosystems on Lembongan Island works well. The Klungkung Regency Government continues to periodically provide guidance and counseling on the importance of the sustainability of marine ecosystem functions on Lembongan Island. The private sector, especially tourism actors are moving to create an activity that supports the conservation of the marine ecosystem on Lembongan Island in the form of clean beach activities and Nusa Penida Festival activities.

The surrounding communities in Lembongan Island also play a very active role in preserving the function of the marine ecosystem on Lembongan Island by adhering to the policies of customary institutions that are mutually agreed upon.

Pekraman village in Lembongan develops traditional institutions similar to Pekraman village in Bali. Some traditional institutions in Lembongan village are BPD, LPD, Adat Village Administrators, Klian Banjar, Klian Dadia, Paruman Pemangku, Sekaa Santi, Sekaa Gong, Seaweed Farmer Groups, Pecalang, and there are some members of the community who are motivated to save the environment. on the island of Lembongan. Besides traditional institutions there is also an agency that regulates the lives of people in the village of Lembongan. These institutions include village officials, hamlet heads, youth organizations, and several NGOs that move in various fields in the life of the Lembongan village community.

Based on the explanation above, to preserve coastal ecology on the coast of the island of Lembongan, several customary institutions and service institutions in the village of Lembongan carry out their functions and duties to invite the people of Lembongan village to jointly preserve the 
ecological sustainability of the sea on the coast of Lembongan. Strengthening this institutional function is carried out by always providing information on the importance of environmental conservation of coastal ecology. Institutional strengthening in the village of Lembongan is the establishment of a special field that deals with the sustainability of the coastal environment. Specific areas that govern the preservation of the coast are in every institution in the village of Lembongan.

In addition to institutional strengthening, the village of Lembongan also includes environmental conservation and the coastal environment in awig-awig villages that regulate the wheel of life for the people of Lembongan. There are several clauses that explicitly regulate coastal sand management, magrove forest management, coral reefs, search for fish in the sea, and specific rules regarding seaweed cultivation. The rules listed in the village awig-awig are also accompanied by strict sanctions if there are community members or outsiders who violate or damage the coastal environment in the Lembongan village area.

Institutional strengthening occurs both at the adat and official levels, between sectors related to handling resource controls such as supervision, controlling pollution of the marine environment. Institutions in Lembongan village already have regulations regarding this handling. Coastal exploration and exploitation activities, shipping and port and beach and sea tourism are also arranged in detail in each of the existing village institutions.

Official institutions in the Klungkung Regency Government are also very instrumental in preserving the marine ecosystem of Lembongan Island. These institutions are the Marine and Fisheries Service of Klungkung Regency, Tourism Office, BLH, and Nusa Penida KKP. These institutions, always provide guidance and understanding to coastal communities the importance of the use and preservation of ecological functions of marine ecosystems.

In saving the marine ecosystem in Lembongan Island, the efforts are carried out by fostering and forming institutions that specifically deal with the problem of marine ecosystems in Lembongan Island. This is in accordance with the results of research conducted by Sudiarta, 2015, in a study "Tropical Marine Ecology" explained that the biodiversity on the coast of Lembongan Island is very good and strongly supports the continuity of the development of marine biota in Lembongan Island. Also explained, this diversity needs to be maintained to support the development of tourism on Lembongan Island. Other similar studies were also carried out by Westmacott, S., K. Teleki, S. Wells and J. West, 2000, in a study entitled "Management of Coral Reefs that Are Whiten and Critically Damaged", concluded the need for an active role for all components in management coral reefs on coastal islands.

The participation of 3 pillars of governance (government, private sector, and the community on the island of Lembongan in general is already good. Tackling the damage, it is expected that residents in coastal areas to be able to maintain the assets contained in the marine environment, are aware of the interests of the sea and its ecosystem, which is as a biological source, stimulates the ability of nature to make the livelihoods of the people around the sea so as to make a welfare of its people.

But the above solution can occur if all parties involved both from the government and community members can work together. It is hoped that with good cooperation between the government and the community, a prosperous maritime country will soon be realized and such things are also expected to be able to overcome the damage to marine ecosystems throughout Indonesia today and beyond.

The researcher argues, from the results of interviews and recording of documents that have been done, that institutional strengthening in Lembongan Island, especially the role of the 3 pillars of governance has been going well. These roles are played in conjunction with the 3 pillar functions. The Klungkung Regency Government has established an official institution which specifically handles the preservation of marine ecosystems in Lembongan Island, namely the KKP which is specifically placed in Nusa Penida in the form of KUPT. Tourism actors have carried out movements that support the sustainability of marine ecosystem functions on Lembongan Island such as Nusa Penida Festival activities. The community has used awig-awig in Pekraman Lembongan village in managing the marine ecosystem on Lembongan Island. 


\section{Conclusion}

The participation of the 3 pillars of governance (government and private parties) on Lembongan Island has played a good role in accordance with its duties and functions, while the community needs to be nurtured more awareness. Tackling the damage, it is expected that residents in the coastal areas of the sea to be able to maintain the assets contained in the marine environment, be aware of the interests of the sea and its ecosystems as a biological resource, preserve the natural ability to make the livelihoods of people around the sea so as to make a welfare of the people.

\section{Recommendation}

The need for an optimal role 3 pillars of governance by creating a special regional regulation established by the Klungkung Regency Government in managing the marine ecosystems on Lembongan Island. The community is advised to always be wise in utilizing marine ecosystems on Lembongan Island, because the marine ecosystem on Lembongan Island is a superior tourism object. Tourism actors are expected to play an active role in the management of marine ecosystems on the island of Lembongan, for example in periodic and continuous activities that support the preservation of marine ecosystems on Lembongan Island. The Klungkung Regency Government immediately consolidated with the relevant agencies so that the Regional Regulation would be realized soon.

The need for awareness of the people of Lembongan Island and tourism actors in managing the marine ecosystem in Lembongan Island. It is also necessary to generate local institutions that are developing in a coastal area to play an active role in managing coastal areas from the threat of danger, both from humans and the dangers of nature. The community must be continuously provided with understanding through counseling on the management of marine ecosystems.

\section{Bibliography}

Anni Milen. 2004. Pegangan Dasar Pengembangan Kapasitas. Diterjemahkan secara bebas. Yogyakarta: Pondok Pustaka Jogja

Bengen, D.G. 2001. Sinopsis Ekosistem dan Sumberdaya Alam Pesisir. Bogor: Pusat Kajian Sumberdaya Pesisir dan Lautan, Instititut Pertanian Bogor.

Darma, Riyanto dan Welly. 2010. Profil Kawasan Konservasi Perairan (KKP) Nusa Penida Kabupaten Klungkung, Propinsi Bali. Coral Triangle Center (CTC), Bali.

Dwiyanto, Agus. 2014. Mewujudkan Good Governance Melalui Pelayanan Publik. Yogyakarta: Gajahmada University Press.

Imam Hardjanto. 2006. Pembangunan Kapasitas Lokal (Local Capacity Building). Malang: Program Pascasarjana Universitas Brawijaya, Malang

Miles, M.B. and Huberman, M.A. 1984. Qualitative Data Analysis. London: Sage Publication

Muhadji, Noeng. Metodologi Penelitian Kualitatif. Yogyakarta: Andi Offset

Nontji, A. 1987. Laut Nusantara. Penerbit Djambatan. Jakarta.

Nybakken, J.W. 1992. Biologi Laut Suatu Pendekatan Ekologis. PT. Gramedia Pustaka Utama. Jakarta. Patilima, Hamid. 2005. Metode Penelitian Kualitatif. Bandung: Alfabeta

Puslitbang Perikanan-Balitbang Pertanian Departement Pertanian. 1996. Peningkatan Visi Sumberdaya Manusia Penelitian Perikanan Menyongsong Globalisasi IPTEK. Prosiding Rapat Kerja Tenis Puslitbang Perikanan, Serpong 19-20 November 2016.

Salm, B.V. and J.R. Clark. 1989. Marine and Coastal Protected Areas. IUCN and Natural Resources Gland, Switzerland. 
Sudiarta, I Ketut. 2015. Ekologi Pesisir Laut Tropis. Denpasar : Jur. Perikanan Unwar

Sudibawa, I Putu, 2016. Eksistensi Kurikulum Muatan Lokal dalam Mendukung Kelestarian Ekosistem Laut. Tesis. Singaraja: Undiksha

Sugiyono. 2008. Memahami Penelitian Kualitatif. Bandung: Alfabeta

Tania, Welly dan Muljadi. 2011. Willingness to Pay Kawasan Konservasi Perairan Nusa Penida Kabupaten Klungkung, Bali. Coral Triangel Center (CTC), Bali.

Welly, dkk. 2011. Profil Wisata Bahari Nusa Penida Kabupaten Klungkung, Provinsi Bali. Coral Triangel Center (CTC)., Bali.

Westmacott, S., K. Teleki, S. Wells dan J. West. 2000. Pengelolaan Terumbu Karang yang Telah Memutih dan Rusak Kritis. IUCN, Gland, Swiss, dan Cambridge.

Undang-undang Republik Indonesia Nomor 1 Tahun 2014 tentang Perubahan Undang-undang tentang Pengelolaan Wilayah Pesisir dan Pulau-pulau Kecil

Undang-undang Republik Indonesia Nomor 45 Tahun 2009 tentang Perikanan

Disbudpar Klungkung. 2016. Kunjungan Wisata. Laporan Tahunan. Pemda Klungkung 